RANDOLPH, L. F. (1932): Some effects of high temperature on polyploidy and other variations in maize. PNAS 18 222-229.

SEITZ, F. W. (1954): The occurrence of triploids after selfpollination of anomalous androgynous flowers of a grey poplar. Z Forstgenet 3: 1-6.

Wang, J., X. Kang, D. Li, H. Chen and P. Zhang (2010): Induction of diploid eggs with colchicine during embryo sac development in Populus. Silvae Genet 59: 40-48.

WANG, J., D. L. LI and X. Y. KANG (2012): Induction of unreduced megaspores with high temperature during megasporogenesis in Populus. Ann Forest Sci. 69. 59-67. doi:10.1007/s13595-011-0152-5.

WinTon, L. and D. W. EinsPaHR (1970): Tetraploid aspen production using unreduced triploid pollen. For Sci 16 180-182.

WU, H., S. Zheng, Y. He, G. YAN, Y. Bi and Y. ZhU (2007): Diploid female gametes induced by colchicine in Oriental lilies. Scientia Horticulturae 114: 50-53.
YANG, H. and X. GUO (2006): Polyploid induction by heat shock-induced meiosis and mitosis inhibition in the dwarf surfclam, Mulinia lateralis Say. Aquaculture 252: 171-182.

Yemets, A. I. and Y. B. Blume (2008): Progress in plant polyploidization based on antimicrotubular drugs. The Open Horticulture Journal 1: 15-20.

Zhang, S. G., C. B. Chen, S. Y. Han, X. L. Li, J. Z. ReN, Y. Q. Zhou, W. Q. Song, R. Y. Chen and L. W. QI (2005): Chromosome numbers of some Populus taxa from China. Acta Phytotaxonomica Sinica 43: 539-544.

Zhang, S., L. QI, C. Chen, X. Li, W. Song, R. Chen and S. HAN (2004): A report of triploid Populus of the section Aigeiros. Silvae Genet 53: 69-75.

Zhang, X. Z., G. J. LiU, L. Y. Yan, Y. B. Zhao, R. F. Chang and L. P. WU (2002): Creating triploid germplasm via induced $2 n$ pollen in Capsicum L. J Horticult Sci Biotechnol 78: 84-88.

ZHU, Z. T., H. B. LIN and X. Y. KANG (1995): Studies on allotriploid breeding of Populus tomentosa B301 clones. Sci Silvae Sinicae 31: 499-505.

\title{
Physiological and Protein Responses to Drought in Four Pine Seedlings
}

\author{
By C. Y. $\mathrm{HE}^{1,2)}$, J. G. ZHANG ${ }^{1,2), 3)}$ and A. G. DuAN ${ }^{1)}$
}

(Received $5^{\text {th }}$ April 2011)

\begin{abstract}
Physiological and protein responses to drought stress in four pine seedlings, Pinus armandi Franch. (Pa), Pinus tabulaeformis Carr. (Pt), Pinus bungeana Zucc. ex Endl. $(\mathrm{Pb})$ and Pinus sylvestris L. var. mongolica Litv. (Ps), were investigated using differential proteomics and water physiological indices. Firstly, the water physiological data showed that the decline rate of net photosynthesis rate, stomatal conductance, leaf water potential, turgor pressure except for under moderate drought stress was as follows: $\mathrm{Pa}>\mathrm{Ps}>\mathrm{Pt}>\mathrm{Pb}$. $\mathrm{Pb}$ and $\mathrm{Pa}$ always maintained the highest and lowest swelling pressure, respectively. Secondly, cluster analysis of 343 proteins indicated that the four pine species were classified into three groups with a genetic distance coefficient of 0.065 . That is, five-needle-pine group $(\mathrm{Pa})$, three-needle-pine

1) State Key Laboratory of Tree Genetic and Breeding, Research Institute of Forestry, Chinese Academy of Forestry, Beijing 100091, P. R. China.

$\left.{ }^{2}\right)$ Key Laboratory of Silviculture of the State Forestry Administration, Research Institute of Forestry, Chinese Academy of Forestry, Beijing 100091, P. R. China.

${ }^{3}$ ) Corresponding author: Dr. JIANGUO ZHANG, Key Laboratory of Silviculture of the State Forestry Administration, Research Institute of Forestry, Chinese Academy of Forestry, Beijing 100091, P. R. China. Tel: +86-10-62889601, Fax: +8610-62872015, E-mail: zhangjg@caf.ac.cn
\end{abstract}

group $(\mathrm{Pb})$, two-needle-pine group ( $\mathrm{Pt}$ and $\mathrm{Ps})$, and the genetic distance between $\mathrm{Pb}$ and $\mathrm{Pa}$ was the farthest. The result was consistent with the declined rate in above physiological indices. Finally, for the differential proteomics analyzed, a total of 13 different proteins $(P$ values $<0.01)$ changed significantly, the number of differentially expressed proteins was more in $\mathrm{Pa}$ (accounting for $46.2 \%$ ) than the other three species, and 8 proteins were identified using matrix-assisted laser desorption/ionization time -of-flight mass spectrometry (MALDI-TOF-MS). These proteins are quite diverse in their functions and involved in photosynthesis, osmotic regulation and functioning as signal transduction. These results suggested that the sensitivities of the four pine species to drought were possibly related to genetic distance.

Key words: drought stress, drought-resistance, proteomics, genetic distance.

\section{Introduction}

Trees in their lifetime are usually subjected to extremely harsh environmental stresses. Drought stress is particularly prominent among a variety of natural stresses associated with predicted changes in climate. Thus, understanding the genetic basis and molecular mechanisms of drought stress adaptation is of particular 
importance for forest tree species given the possibility of future rapid climatic changes.

Studies on the drought resistance of forest tree species have mostly focused on changes in physiological adaptation, such as photosynthesis (BASSMAN and ZwIER, 1991; DICKMAN et al., 1992; NI and PALLARDY, 1992), transpiration (SCHLTE and MoRSHALL, 1982), respiration (ZHANG, 2000), physiological mechanisms, such as antioxidant defense (Hu et al., 1999), stomatal regulation (RHODENBANGH and PALLARDY, 1993), osmotic adjustment (KosTer, 1991), and hormonal regulation mechanism (AASAMAA et al., 2002; ROBERT and LENOBLE, 2002). Recently, molecular studies on stress responsive gene expression, protein and metabolite profiling in forest tree species have been undertaken. As a large-scale study of proteins, proteomics is now being widely applied to many forest tree species, such as the maritime pine (Costa et al., 1999; GiON et al., 2005), Huashan pine (HE et al., 2007), Monterey pine (VALleDOR et al., 2010), poplar (RENAUT et al., 2004; PLOMION et al., 2006; Bogeat-Triboulot et al., 2007; He et al., 2008), spruce (LIPPERT et al., 2005) and oak (JORGE et al., 2006). Also, there are some reports on the application of proteomics to the study of responses of forest trees to drought (CostA et al., 1998; JoRGE et al., 2006; PlOMION et al., 2006; Bogeat-TRIBoulot et al., 2007; HE et al., 2007,2008 ). These works established the validity of the technique in screening drought-induced protein variations, and offered important information about the practical application of proteomic studies for understanding the molecular mechanisms of stress response and forest yield.

In our previous research (ZHANG et al., 2000), we have systematically studied the drought tolerance characteristics of 32 different afforestation tree species in Northern China, and divided these trees into two types and 4 subtypes according to water eco-physiological characteristics. We have concluded that Pinus armandi Franch. (Pa), Pinus tabulaeformis Carr. (Pt), Pinus bungeana Zucc. ex Endl. (Pb), Pinus sylvestris L. var. mongolica Litv. (Ps) belong to the high potential delay dehydration species based on their drought-resistance mechanism. This study aims to investigate the molecular mechanism and sensitivity difference of the four pine species applying proteomics and physiology technology, and we hope to provide some insights into the selection of forest tree species and molecular breeding in the arid and subarid areas of Northern China.

\section{Materials and Methods}

\section{Plant material and treatment}

Three-year-old seedlings (1-2 cm in diameter, 20-30 $\mathrm{cm}$ in height) of Pinus armandi Franch. (Pa, five needles in one bundle), Pinus tabulaeformis Carr. (Pt, two needles in one bundle), Pinus bungeana Zucc. ex Endl. (Pb, three needles in one bundle), Pinus sylvestris L. var. mongolica Litv. (Ps, two needles in one bundle) were transplanted into $18 \mathrm{~cm} \times 26 \mathrm{~cm} \times 34 \mathrm{~cm}$ plastic pots containing $10 \mathrm{~kg}$ of a mixture of clay soil/sand/peat moss (5:3:2) and grown for three months in a naturally-lighted greenhouse under a $25 / 20^{\circ} \mathrm{C}$ (day/night) regime, a relative humidity $(\mathrm{RH})$ of $80 \sim 90 \%$, and a $\mathrm{CO}_{2}$ concentration of $375 \pm 10 \mathrm{\mu mol} \cdot \mathrm{mol}^{-1}$. Shading was utilized when the photosynthetic photon flux density exceeded the light saturation point (about $800 \mu \mathrm{mol} \mathrm{m} \mathrm{m}^{-2} \mathrm{~s}^{-1}$ ). Thereafter, the plants were divided into three groups on June 26, 2005. At the beginning of the experiment, the soil water potential $\left(\psi_{\text {swp }}\right)$ was brought to about -0.5 MPa.

Three treatments (T0, T1 and T2), each with three biological replicates, were applied as follows. T0 was an unstressed control, in which $\psi_{\text {swp }}$ was maintained at about $-0.5 \mathrm{MPa}$ by regular watering during the whole experiment (i.e., from day 0 to day 15). Six current-year fresh needle samples were taken from each seedling for protein extraction on day 7 and 15 . T1 was the moderate drought stress treatment, in which watering was withheld until the $\psi_{\text {swp }}$ was brought to about -1.5 MPa (around day 7), three seedlings were harvested for protein extraction. T2 was the severe drought stress treatment, in which watering was withheld until the $\psi_{\text {swp }}$ was brought to about $-3.0 \mathrm{MPa}$ (around day 15), three seedlings were harvested for protein extraction.

\section{Measurements of stomatal conductance (Gs), net photosynthetic rates $(P n)$ and leaf water potential $\left(\psi_{\text {lwp }}\right)$}

Measurements of Gs and Pn were determined three times at around nine o'clock in the morning with a LI6400 Portable Photosynthesis System (LI-COR, Inc., Lincoln, NE, USA) (CUI et al., 2006), and the changes in Pn and Gs in the four pine species were shown in Figure $1 A$ and $B$. Pre-dawn $\psi_{\text {swp }}$, an indicator of plants' water status, was measured using the WP4 Dewpoint Potential Meter (Decagon Devices, Inc., Pullman Washington, USA). The leaf water potential $\left(\psi_{\text {lwp }}\right)$ was measured using plant pressure chamber (A-3000) (Spectronics Corporation, USA) (Figure 1D). Turgor pressure $\left(\psi_{\mathrm{p}}\right)$ was estimated by the pressure-volume $(p \mathrm{~V})$ curves using pressure chamber (TYREE and HAMMEL, 1972; LI, 1989; ZHANG and ZHENG, 2012), the methods were as follows: $p \mathrm{~V}$ curve of each tree were made in the mild drought stress $\left(\psi_{\text {lwp }}:-0.5 \sim-1.0 \mathrm{MPa}\right)$, moderate drought stress $\left(\psi_{\text {lwp }}:-1.5 \sim-2.0 \mathrm{MPa}\right)$, severe drought stress $\left(\psi_{\text {lwp }}:<-2.0 \mathrm{MPa}\right)$, and the linear relationship between the $\psi_{\mathrm{p}}$ and $\psi_{\text {lwp }}$ was estimated according to $p \mathrm{~V}$ curve, finally $\psi_{\mathrm{p}}$ was calculated (Figure $1 C$ ). The linear relationship between $\psi_{\mathrm{p}}$ and $\psi_{\text {lwp }}$ was shown in Table 1 (ZHANG et al., 2000).

\section{Two-dimensional gel electrophoresis (2-DE) and gel analysis}

Needle proteins were extracted as described previously (HE et al., 2005). Proteins from $2 \mathrm{~g}$ needles were extracted in $20 \mathrm{~mL}$ extraction buffer (5\% sucrose, $4 \%$ sodium dodecyl sulfate (SDS) and 5\% 2-mercaptoethanol) with the addition of $0.2 \mathrm{~g}$ polyvinylpoly pyrrolidone (PVPP) for $10 \mathrm{~min}$ at room temperature with gentle stirring, followed by centrifugation at $10,000 \times \mathrm{g}$ for $20 \mathrm{~min}$. The clear supernatant was heated at $100^{\circ} \mathrm{C}$ for $3 \mathrm{~min}$ and then precipitated with eight volumes of cold acetone containing $0.07 \%$ 2-mercaptoethanol. After at least $1 \mathrm{~h}$ at $-20^{\circ} \mathrm{C}$, the mixture was 


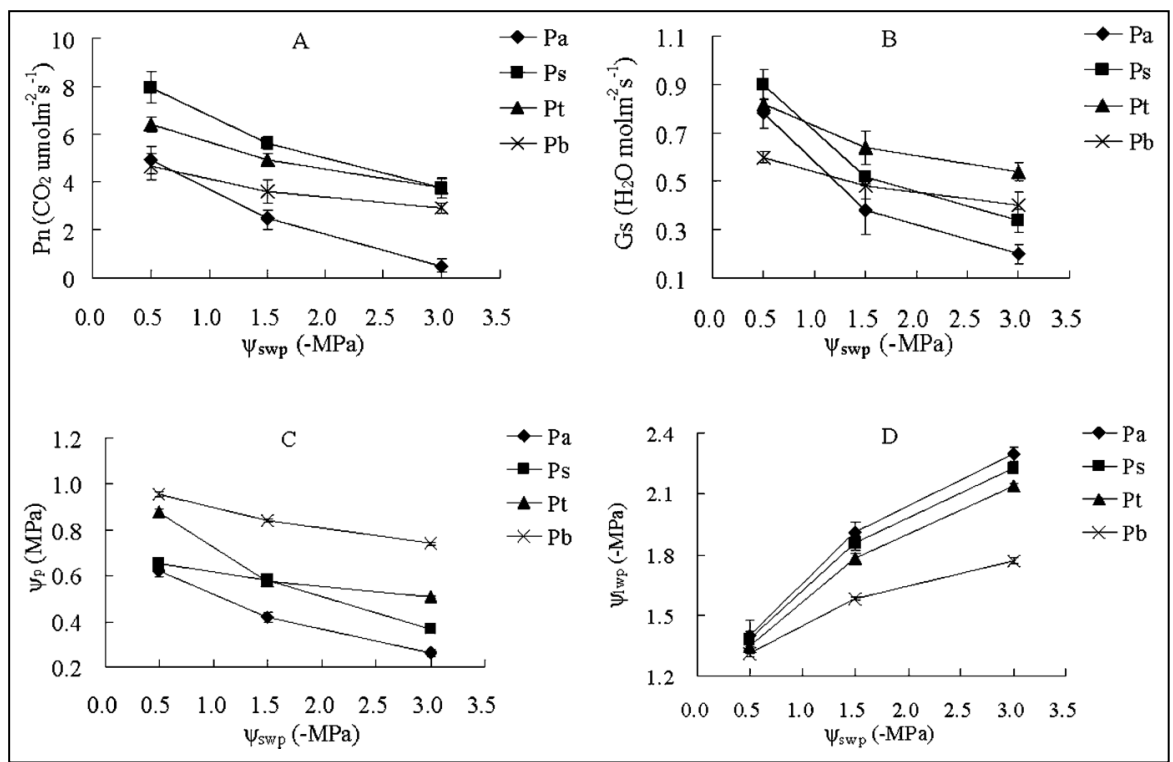

Figure 1. - Progression of Pn (A), Gs (B), $\psi_{\mathrm{p}}(\mathrm{C})$ and $\psi_{\mathrm{lwp}}(\mathrm{D})$ of Pinus armandi Franch. $(\mathrm{Pa})$, Pinus tabulaeformis Carr. (Pt), Pinus bungeana Zucc. ex Endl. (Pb), and Pinus sylvestris L. var. mongolica Litv. (Ps) during drought treatment. Statistical analysis (two-way ANOVA) indicated the differences in $\mathrm{Pn}, \mathrm{Gs}, \psi_{\mathrm{p}}$ and $\psi_{\mathrm{lwp}}$ were significant between species and at different soil water potentials $(P$ values $<0.05)$.

Table 1. - The relationship between the $\psi_{\mathrm{p}}$ and $\psi_{\mathrm{lwp}}\left(\psi_{\mathrm{p}}=\mathrm{a}+\mathrm{b} \psi_{\mathrm{lwp}}\right)$.

\begin{tabular}{|c|c|c|c|c|c|c|c|c|c|c|c|}
\hline Speeics & $\begin{array}{l}\psi_{\text {swp }} \\
(\mathrm{MPa})\end{array}$ & $\begin{array}{l}\psi_{\text {lwp }} \\
(\mathrm{MPa})\end{array}$ & a & b & $\mathrm{R}^{2}$ & Species & $\begin{array}{l}\psi_{\mathrm{swp}} \\
(\mathrm{MPa})\end{array}$ & $\begin{array}{l}\psi_{\text {lwp }} \\
\text { (MPa) }\end{array}$ & $\mathrm{a}$ & b & $\mathbf{R}^{2}$ \\
\hline \multirow{3}{*}{$\mathrm{Pa}$} & $-0.5+0.10$ & $-1.40+0.07$ & 1.1919 & 0.4053 & 0.9698 & \multirow{3}{*}{$\mathrm{Pt}$} & $-0.5+0.07$ & $-1.35+0.03$ & 1.6445 & 0.5719 & 0.9913 \\
\hline & $-1.5 \pm 0.15$ & $-1.91 \pm 0.05$ & 1.1919 & 0.4053 & 0.9698 & & $-1.5 \pm 0.01$ & $-1.78 \pm 0.02$ & 1.4440 & 0.4885 & 0.9612 \\
\hline & $-3.0 \pm 0.15$ & $-2.29 \pm 0.04$ & 1.1919 & 0.4053 & 0.9698 & & $-3.0 \pm 0.04$ & $-2.14 \pm 0.01$ & 1.6564 & 0.5372 & 0.9993 \\
\hline \multirow{3}{*}{ Ps } & $-0.5+0.05$ & $-1.38+0.04$ & 1.6395 & 0.7148 & 0.9996 & \multirow{3}{*}{$\mathrm{Pb}$} & $-0.5+0.04$ & $-1.31+0.02$ & 1.9594 & 0.7669 & 0.9971 \\
\hline & $-1.5+0.10$ & $-1.86+0.03$ & 1.6725 & 0.5886 & 0.9934 & & $-1.5+0.05$ & $-1.58+0.01$ & 1.6980 & 0.5412 & 0.9831 \\
\hline & $-3.0 \pm 0.11$ & $-2.22 \pm 0.02$ & 1.6725 & 0.5886 & 0.9934 & & $-3.0 \pm 0.14$ & $-1.77 \pm 0.01$ & 1.6980 & 0.5412 & 0.9831 \\
\hline
\end{tabular}

Pa, Pinus armandi Franch.; Pt, Pinus tabulaeformis Carr.; Pb, Pinus bungeana Zucc. ex Endl.; Ps, Pinus sylvestris L. var. mongolica Litv.; $\psi_{\text {p }}$, turgor pressure; $\psi_{\text {lwp }}$, leaf water potential; $\psi_{\text {swp }}$, pre-dawn soil water potential.

centrifuged at $10,000 \times \mathrm{g}$ for $20 \mathrm{~min}$. The pellet was resuspended in $10 \mathrm{~mL}$ of extraction buffer and centrifuged at $10,000 \times \mathrm{g}$. After washing once or twice with $80 \%$ cold acetone, the pellet was precipitated by adding four volumes of cold acetone, and then was lyophilized and solubilized with $12.5 \mu \mathrm{L}$ lysate buffer per $1 \mathrm{mg}$ of pellet. Concentrations were determined by the Bradford method (BRADFORD, 1976). For isoelectric focusing (IEF), the IPGphor system (Amersham Biosciences, Uppsala, Sweden) and $\mathrm{pH} \tilde{3}-10$ immobilized $\mathrm{pH}$ gradient (IPG) strips (18 cm, nonlinear) were used. A total of $1.2 \mathrm{mg}$ combined proteins was mixed with a strip rehydration solution (8 mol L ${ }^{-1}$ urea, 2\% 3-[(3-cholamidopropyl) dimethylammonio]-1-propane sulphonate (CHAPS), $20 \mathrm{mmol} \mathrm{L}^{-1}$ dithiothreitol (DTT), 0.5\% IPG buffer and trace bromophenol blue). The IPGphor system was then programmed as follows: $12 \mathrm{~h}$ (active rehydration), $1 \mathrm{~h}$ at $500 \mathrm{~V}, 1 \mathrm{~h}$ at $1000 \mathrm{~V}$, and $\tilde{8}-10 \mathrm{~h}$ at $8000 \mathrm{~V}$. The focused strips were equilibrated twice for $15 \mathrm{~min}$ in $10 \mathrm{~mL}$ equilibration buffer ( $50 \mathrm{mmol} \mathrm{L}^{-1}$ Tris-HCl, $\mathrm{pH} 8.8,6 \mathrm{~mol} \mathrm{~L}^{-1}$ urea, $30 \%(\mathrm{v} / \mathrm{v})$ glycerol and $2 \%(\mathrm{w} / \mathrm{v})$ SDS) containing $100 \mathrm{mg}$ DTT with gentle shaking. During the second equilibration, $250 \mathrm{mg}$ iodoacetamide was used instead of DTT. Sodium dodecyl sulfate-polyacrylamide gel electrophoresis (SDS-PAGE) was performed using a PROTEAN II xi Cell (Bio-Rad, Hercules, California, USA). A total of 48 2-D gels (15\% acrylamide) were stained with Coomassie Brilliant Blue (CBB) R-250, and images of the gels were captured with a scanner (UMAX Powerlook 2100 XL; UMAX, Taiwan, China).

Forty-eight gels were digitized and analyzed using ImageMaster $^{\mathrm{TM}}$ 2D Platinum Software (Version 5.0; Amersham Biosciences, Uppsala, Sweden) for spot detection, spot matching, background subtraction, normalization and statistical analyses. The spot detection was initially performed with software automatically. 
Since many spots were omitted or were not circled properly by the automatic mode, spot detection was corrected manually. $T$-test was performed to determine the significant differences between two groups. $P$ values $<0.01$ were considered statistically significant. The spot of interest was selected if significant changes did not occur between different stages of control samples (excluding developmental differences), but did occur between control and treated samples at the same stage.

\section{Matrix-assisted laser desorption/ionization time of flight mass spectrometry (MALDI-TOF MS) analysis}

CBB-stained protein spots were excised manually from the gels and washed three times with ultra-pure water. Spots were washed subsequently in destaining buffer [50\% acetonitrile (ACN), $\left.25 \mathrm{mmol} \mathrm{L}^{-1} \mathrm{NH}_{4} \mathrm{HCO}_{3}\right]$ and freeze-dried. The gels were swollen for $1 \mathrm{~h}$ at $4{ }^{\circ} \mathrm{C}$ in $10 \mathrm{ng} \mu \mathrm{L}^{-1}$ trypsin (Sequencing grade modified Trypsin; Promega, Madison, USA) in $20 \mathrm{mmol} \mathrm{L}^{-1} \mathrm{NH}_{4} \mathrm{HCO}_{3}$ and incubated for $16 \mathrm{~h}$ at $37^{\circ} \mathrm{C}$.

The spots were incubated for $1 \mathrm{~h}$ in $5 \%$ trifluoroacetic acid (TFA) at $37^{\circ} \mathrm{C}$, and the supernatant was removed and saved in an Eppendorf tube. Then the spots were incubated for $1 \mathrm{~h}$ in $2.5 \% \mathrm{TFA} / 50 \% \mathrm{ACN}$ at $30^{\circ} \mathrm{C}$ and the second supernatant was pooled with the first supernatant. Next $5 \mu \mathrm{L}$ of $100 \%$ ACN was added to the spots for $5 \mathrm{~min}$, the third supernatant was pooled with the two former supernatants and then lyophilized. MS analysis was conducted with a MALDI-TOF MS (Voyager DE-Pro; Applied Biosystems, Framingham, MA, USA) in reflector mode over a mass range of 500-3,500 Da. The $0.2 \mu l$ peptide mixture was mixed with $0.2 \mu \mathrm{l}$ matrix solution (a-cyano-4-hydroxycinnamic acid, $5 \mathrm{mg} / \mathrm{ml}$ in $100 \%$ methanol) on the target plate. For each sample, spectra from 100 shots at several different positions were combined to generate a peptide mass fingerprint $(\mathrm{PMF})$ for database searches for protein identification. The PMF obtained from each digested protein were compared with PMFs in the nonredundant National Center for Biotechnology Information database (NCBInr) using Mascot search (Matrix Science, http://www.matrixscience.com/). The search was performed within green plants (Viridiplantae). A mass tolerance of $\pm 100 \mathrm{ppm}$ and one incomplete cleavage was allowed, Oxidation (M) as Variable modifications was selected.

\section{Data analysis}

The presence or absence of protein spots was scored as 1 or 0 respectively. The data were analyzed using NTSYSpc2.10e (NEI, 1972). Coefficients of genetic distances and similarity based on pairwise comparisons for protein profiles (12 individuals) among the four pine species were calculated. Due to the bad definition of the borders, only the spots located in a central zone of the 2$\mathrm{D}$ gels were retained. Reference gels were created for each patch, and then matched together one after the other, leading to a global synthetic gel. Statistical analysis of the eco-physiological data (Pn, Gs, $\left.\psi_{\text {lwp }}, \psi_{\text {swp }}, \psi_{\mathrm{p}}\right)$ was performed using Microsoft Office Excel and SPSS $16.0, P$ values $<0.05$ were considered statistically significant.

\section{Results and Discussion}

Progression of physiological characteristic, pre-dawn leaf water potential $\left(\psi_{\text {lwp }}\right)$ and turgor pressure $\left(\psi_{p}\right)$ during drought stress

Under drought stress, we analyzed the changes of net photosynthetic rate $(\mathrm{Pn})$, stomatal conductance (Gs), turgor pressure $\left(\psi_{\mathrm{p}}\right)$ and leaf water potential $\left(\psi_{\text {lwp }}\right)$ value in the four pine species $(\mathrm{Pa}, \mathrm{Ps}, \mathrm{Pt}, \mathrm{Pb})$. Statistical analysis (two-way ANOVA) indicated the differences in Pn, Gs, $\psi_{\mathrm{p}}$ and $\psi_{\text {lwp }}$ were significant between species and at different soil water potentials $(P$ values $<0.05)$. With increasing degree of drought stress, Pn and Gs decreased gradually (Figure $1 A$ and $B$ ), and the decline rate under T1 and T2 stresses was as follows: $\mathrm{Pa}>\mathrm{Ps}>$ $\mathrm{Pt}>\mathrm{Pb}$ (Figure 2). Our previous study (ZhANG et al., 2000) has pointed out that the Pn of seedlings decreased significantly under drought stress, and the tree species

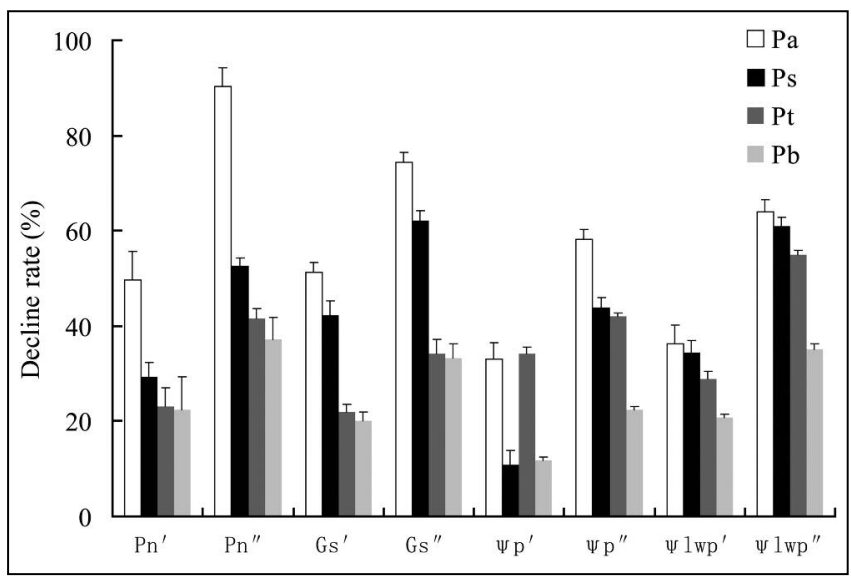

Figure 2. - Declined rate of Pn, Gs, $\psi_{\mathrm{p}}$ and $\psi_{\text {lwp }}$ of Pinus armandi Franch. (Pa), Pinus tabulaeformis Carr. (Pt), Pinus bungeana Zucc. ex Endl. (Pb), and Pinus sylvestris L. var. mongolica Litv. (Ps) under different drought stress; Pn', Gs', $\psi_{\mathrm{p}}$ and $\psi_{\text {lwp }}$ represent the declined rate under moderate drought stress; Pn", Gs", $\psi_{\mathrm{p}}$, and $\psi_{\mathrm{lwp}}$ represent the declined rate under severe drought stress.

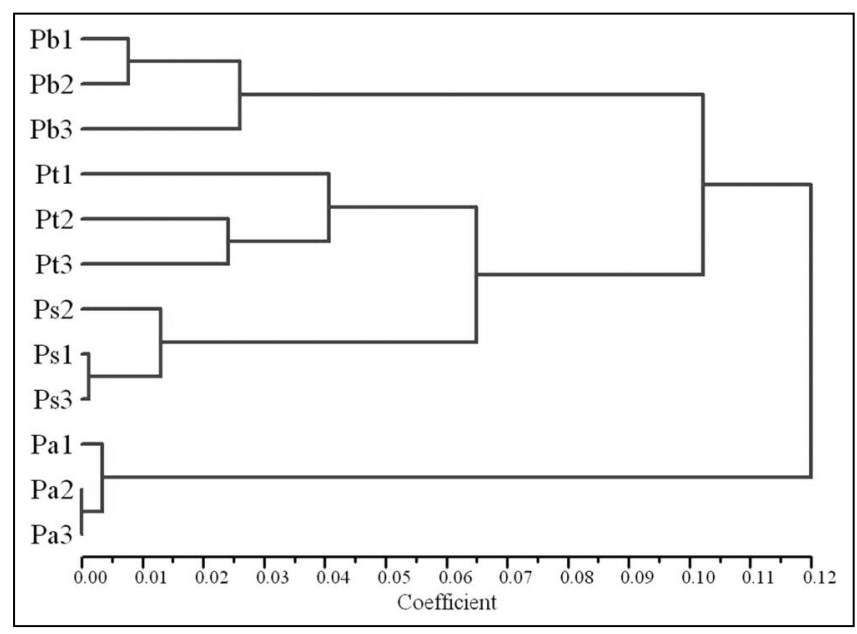

Figure 3. - The dendrogram of polymorphism site of Pinus armandi Franch. (Pa), Pinus tabulaeformis Carr. (Pt), Pinus bungeana Zucc. ex Endl. (Pb), and Pinus sylvestris L. var. mongolica Litv. (Ps) proteins based on genetic distance. 
Supplementary Table 1. - Genetic similarity coefficients within the four pine species.

\begin{tabular}{lllll}
\hline & $\mathrm{Pa}$ & $\mathrm{Ps}$ & $\mathrm{Pl}$ & $\mathrm{Pb}$ \\
$\mathrm{Pa}$ & 1.0000 & & & \\
$\mathrm{PS}$ & 0.9194 & 1.0000 & & \\
$\mathrm{Pt}$ & 0.8922 & 0.9472 & 1.0000 & \\
$\mathrm{~Pb}$ & 0.8562 & 0.8997 & 0.9116 & 1.0000 \\
\hline
\end{tabular}

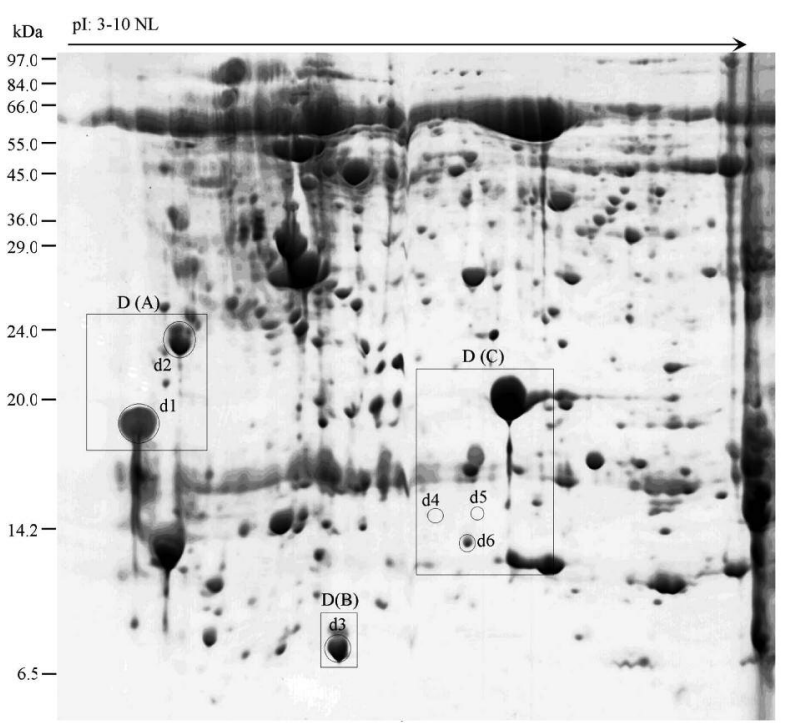

A

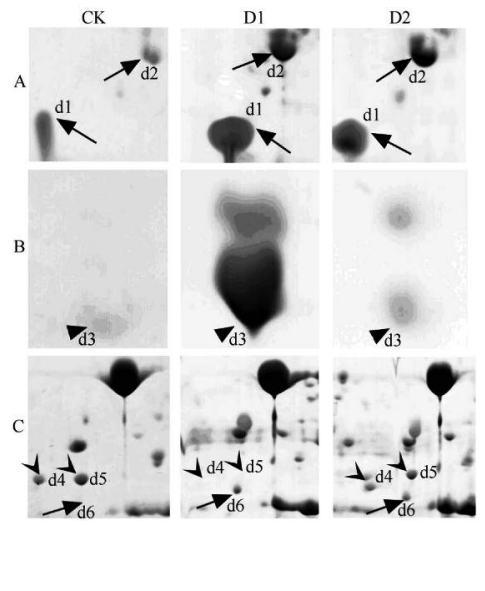

B

Supplementary Figure 1. - Representative CBB-stained 2-D gel of needle proteins in response to drought stress in $P$. armandii Franch (4A). The proteins were separated by IEF/SDS-PAGE. Locations of the 6 drought responsive proteins are indicated by open circles and target plots (framed regions) in D (A, B, C). The framed regions are enlarged in Supplementary Fig. 1 B. Needles were sampled on normal water, moderate drought stress $\left(\psi_{\text {swp }} \approx-1.5 \mathrm{MPa}\right)$ and severe drought stress $\left(\psi_{\text {swp }} \approx-3.0 \mathrm{MPa}\right)$ (i.e. Panel CK, Panel D1 and D2), and the 2-D gels were analyzed. $\uparrow$ point to spots whose intensity notably increased (total 3 spots), $\boldsymbol{\Delta}$ point to spots whose intensity notably increased at moderate drought stress and decreased at severe drought stress (total 1 spots) and $\checkmark$ point to the spots whose intensity decreased at moderate drought stress and increased at severe drought stress (total 2 spot) (B). The detailed changes of ratio were showed in Table 2.

were more sensitive to water deficit when the decline rate of $\mathrm{Pn}$ was much larger. It is more likely that drought affects the ability of the plant to conduct water to leaves to support the stomata opening, transpiration, and finally, $\mathrm{CO}_{2}$ assimilation. The highest $\psi_{\mathrm{p}}$ value was always maintained in the $\mathrm{Pb}$ of the four pine species under drought stress, while the lowest $\mathrm{p}$ value in the $\mathrm{Pa}$ (Figure $1 C$ ) and the decline rate under T2 stress was as follows: $\mathrm{Pa}>\mathrm{Ps}>\mathrm{Pt}>\mathrm{Pb}$ (Figure 2). Hsiao et al (HsiAO et al., 1973, 1985) pointed out maintenance of a certain degree of swelling pressure was very important for plant growth and survival when their water potential declined. Besides, the lowest $\psi_{\text {lwp }}$ value was always maintained in the $\mathrm{Pa}$ of four pine species under drought stress, while the highest in the $\mathrm{Pb}$ (Figure 1D). The declined rate of $\psi_{\text {lwp }}$ was as follows: $\mathrm{Pa}>\mathrm{Ps}>\mathrm{Pt}>\mathrm{Pb}$ (Figure 2). These results possibly indicated that in the four pine species, $\mathrm{Pa}$ was the most sensitive to drought stress, followed by $\mathrm{Ps}, \mathrm{Pt}$ and $\mathrm{Pb}$.

\section{The clustering analysis based on protein} polymorphism site

Based on the established sucrose extraction method of needle protein (HE et al., 2005), 343 proteins separated with 2-dimensional electrophoresis (2-DE) from the four pine species under T0 control treatment were analyzed by UPGMA cluster system, and the genetic distance varied from 0.05 to 0.16 . UPGMA cluster analysis indicated that the four pine species were classified into three groups when genetic distance coefficient was about 0.065 (Figure 3). That is, one was five-needle-pine group $(\mathrm{Pa})$, one was three-needle-pine group $(\mathrm{Pb})$, and the other was two-needle-pine group ( $\mathrm{Pt}$ and $\mathrm{Ps}$ ). The genetic similarity coefficient between $\mathrm{Pb}$ and $\mathrm{Pa}, \mathrm{Pt}$, Ps was 0.86, 0.91, 0.90 (Supplementary Table 1), respectively. It suggested that the genetic relationship between $\mathrm{Pb}$ and $\mathrm{Pa}$ was farther than that between $\mathrm{Pb}$ and another two. The result was consistent with the declined rate in Pn, 


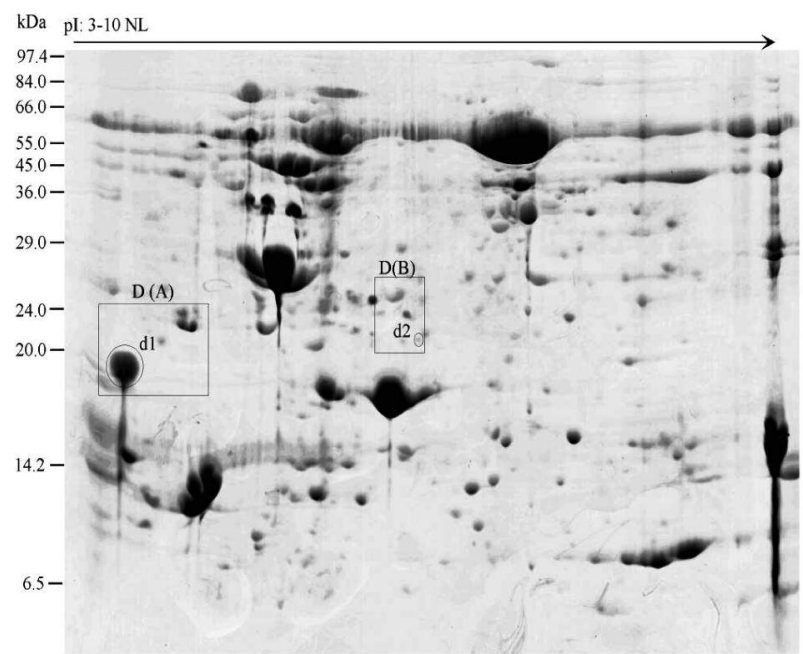

A
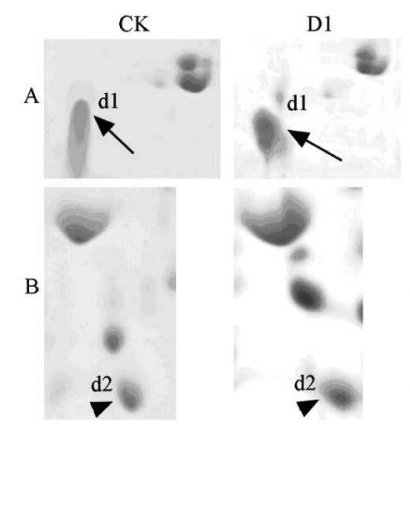

B

Supplementary Figure 2. - Representative CBB-stained 2-D gel of needle proteins in response to drought stress in $P$. tabulaeformis Carr. The proteins were separated by IEF/SDS-PAGE. Locations of the 2 drought responsive proteins are indicated by open circles and target plots (framed regions) in D (A, B). The framed regions are enlarged in Supplementary Fig. 2B. Needles were sampled on normal water, moderate drought stress $\left(\psi_{\text {swp }} \approx-1.5 \mathrm{MPa}\right)$ and severe drought stress $\left(\psi_{\text {swp }} \approx-3.0\right)$ (i.e. Panel CK, Panel D1 and D2), and the 2-D gels were analyzed. $\uparrow$ point to spots whose intensity notably increased (total 1 spots), $\boldsymbol{\Delta}$ point to spots whose intensity notably increased at moderate drought stress and decreased at severe drought stress (total 1 spots) (B). The detailed changes of ratio were showed in Table 2.

Table 2. - Identification of needle proteins responding to drought stress using protein fingerprinting (MALDI-TOF MS).

\begin{tabular}{|c|c|c|c|c|c|c|c|c|c|c|c|}
\hline \multirow{2}{*}{ Index no." } & \multirow{2}{*}{$\begin{array}{l}\text { Theoretical } \\
\text { Mass (kDa) }\end{array}$} & \multicolumn{3}{|c|}{ Experimental } & \multirow{2}{*}{ Sequences cover $(\%)^{\mathrm{h}}$} & \multirow{2}{*}{ Similar protcins } & \multirow{2}{*}{ Spccics } & \multirow{2}{*}{ NCBI accession no. } & \multicolumn{3}{|c|}{ Stress behaviour of spots } \\
\hline & & $\mathrm{pI}$ & Mass (kDa) & $\mathrm{pl}$ & & & & & $C K$ & D1/T & $\mathrm{D} 2$ \\
\hline Padl & 45.6 & 5.49 & $15-24$ & $3.3-3.8$ & 32 & MAPK & Solamm tuberosum & gi $\mid 21165523$ & $\mathrm{l}$ & 6.5289 & 6.6612 \\
\hline $\operatorname{Pad} 2$ & & & $18-25$ & $3.9-4.5$ & & Unidentificd & & & 1 & 3.7819 & 3.9582 \\
\hline Pad3 & & & $6-15$ & $5,2-5.7$ & & Unidentified & & & 1 & 9.7756 & 2.8851 \\
\hline Pad4 & 51.5 & 6.18 & $12-16$ & $5.5-6.2$ & 28 & RuBisCOLSU ${ }^{d}$ & Fagonia cretica & gi 16687544 & 1 & 0.1301 & 1.2147 \\
\hline Pad5 & & & $13-18$ & $5.7-6.2$ & & Unidentified & & & 1 & 0.1058 & 1.1621 \\
\hline Pado & 12.6 & 8.57 & $12-16$ & $5.7-6.5$ & 29 & putative translation factor & Pimus pinaster & gi|20218809 & 1 & 1.6322 & 1.7085 \\
\hline Ptdl & 45.6 & 5.49 & $15-24$ & $3.8-4.3$ & 32 & MAPK ${ }^{\circ}$ & Solanum tuberosum & gi $\mid 21165523$ & 1 & 1.2562 & 1.8256 \\
\hline Ptd2 & & & $16-25$ & $5.8-6.3$ & & Unidentilied & & & 1 & 1.3140 & 0.1524 \\
\hline Pbd1 & & & $6-15$ & $6.5-7.0$ & & Unidentilied & & & 1 & 5.5266 & 6.3741 \\
\hline $\mathrm{Pbd} 2$ & & & $18-24$ & $6.1-6.7$ & & Unidentilied & & & 1 & 3.1245 & 1.2243 \\
\hline Pbd3 & & & $30-36$ & $6.3-6.9$ & & Unidentified & & & 1 & 2.8872 & 3.5571 \\
\hline Psd1 & 25.5 & 6.25 & $18-27$ & $5.7-6.3$ & 48 & dehydrin & Glycine max & gi|37495453 & 1 & 0.8406 & 1.1017 \\
\hline Psd2 & 4.0 & 9.39 & $12-21$ & $6.7-7.5$ & 91 & Pholosystem | H protein & Camptochate deffexa & g| $\mid 33307527$ & 1 & 0.0810 & 0.0745 \\
\hline
\end{tabular}

a Pads $=$ needle proteins of $P$. armandi Franch from drought experiment (Supplementary Figure 1),

Ptds $=$ needle proteins of $P$. tabulaeformis Carr. from drought experiment (Supplementary Figure 2),

$\mathrm{Pbds}=$ needle proteins of $P$. bungeana Zucc. ex Endl. from drought experiment (Supplementary Figure 3),

Psds = needle proteins of P. sylvestris L. var. mongolica Litv. from drought experiment (Supplementary Figure 4),

b Percentage of amino acids in reference protein covered by matching peptides from MALDI-TOF analysis.

${ }^{c}$ MAPK: mitogen-activated protein kinase.

${ }^{\mathrm{d}}$ RuBisCO LSU: ribulose-1,5-bisphosphate carboxylase/oxygenase large subunit.

e The change of fold in different proteins divided by reference gels (controls) during drought stress.

Gs, $\psi_{\text {lwp }}$ and $\psi_{\mathrm{p}}$ value except for $\psi_{\mathrm{p}}$ under T1 stress, that is, $\mathrm{Pa}>\mathrm{Ps}>\mathrm{Pt}>\mathrm{Pb}$, suggesting that the sensitivity to drought was possibly related to genetic relationship based on UPGMA dendrogram of polymorphism site of proteins, and it is necessary to deeply discuss the molecular variance in stress tolerance of these pine species using proteomics method.

\section{Variations of drought responsive proteins in the four pine species}

More than 500 reproducible leaf proteins were detected by 2-DE. Six differential proteins were notably affected by drought stress in $P$. armandi Franch. Of which, three (Pad1, Pad2, Pad6) showed an increase in intensity, one (Pad3) showed increased intensity when $\psi_{\text {swp }}$ values reached about $-1.5 \mathrm{MPa}$ and decreased intensity when $\psi_{\text {swp }}$ values reached about -3.0 $\mathrm{MPa}$, and two showed decreased intensity when $\psi_{\text {swp }}$ values reached about $-1.5 \mathrm{MPa}$ and increased intensity when $\psi_{\text {swp }}$ values reached about $-3.0 \mathrm{MPa}$ during drought stress (Supplementary Figure $1 A$ and $1 B$; Table 2 and 3 ).

Two differential proteins were notably affected by drought stress in P. tabulaeformis Carr.. Of which one (Ptd1) showed an increase in intensity, one (Ptd2) showed increased intensity when $\psi_{\text {swp }}$ values reached about -1.5 $\mathrm{MPa}$ and decreased intensity when $\psi_{\text {swp }}$ val- 
Table 3. - Needle proteins responding to drought stress in four pine species.

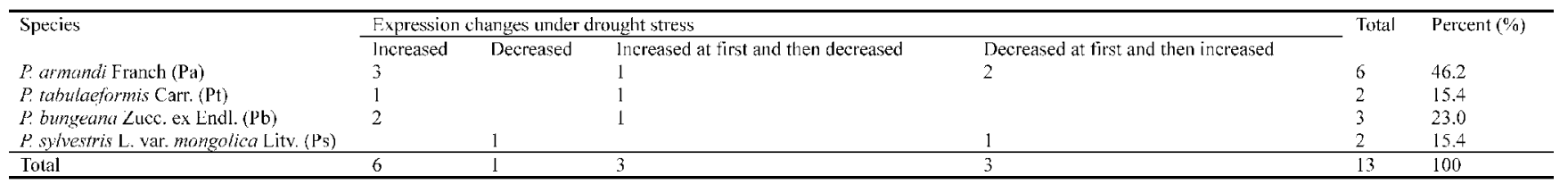

ues reached about -3.0 MPa during drought stress (Supplementary Figure $2 A$ and $2 B$; Table 2 and 3 ).

Three differential proteins were notably affected ( $p$-value $<0.01)$ by drought stress in the $P$. bungeana Zucc.ex Endl.. Of which, two (Pbd1, Pbd3) showed an increase in intensity, one (Pbd2) showed increased intensity when $\psi_{\text {swp }}$ values reached about $-1.5 \mathrm{MPa}$ and decreased intensity when $\psi_{\text {swp }}$ values reached about $-3.0 \mathrm{MPa}$ during drought stress (Supplementary Figure $3 A$ and $3 B$; Table 2 and 3 ).

Two differential proteins were notably affected ( $p$-value $<0.01)$ by drought stress in the P. sylvestris L. var. mongolica Litv. Of which, one (Psd1) showed decreased intensity when $\psi_{\text {swp }}$ values reached about $-1.5 \mathrm{MPa}$ and increased intensity when $\psi_{\text {swp }}$ values reached about $-3.0 \mathrm{MPa}$, one (Psd2) showed a decline in intensity during drought stress (Supplementary Figure $4 A$ and $4 B$; Table 2 and 3 ).

\section{Functional annotation of stress proteins}

In our study, thirteen proteins were found to change very significantly $(p$-value $<0.01)$ in abundance under drought stress. These proteins are mainly involved in functional proteins (dehydrins, Photosystem II $\mathrm{H}$ protein, Ribulose-1,5-bisphosphate carboxylase oxygenase) and regulatory proteins (mitogen-activated protein kinase, putative translation factor).

The activity and abundance of many functional proteins changed through their regulation of signal transduction and gene expression. Plants will establish a new balance according to their interaction under drought stress. In this study we found some osmotic regulation proteins, such as dehydrins and photosynthesis proteins (photosystem II H protein, ribulose 1,5 - bisphosphate carboxylase/oxygenase large subunit).

Dehydrins (DHN), also known as late embryogenesis proteins (LEA), are members of a protein family that are expressed after plants are exposed to stresses with a dehydrative component such as drought, low temperature, salinity and ABA (WELLING et al., 2004; PUHAKAINEN et al., 2004; RORAT et al., 2006; WACHOWIAK et al., 2009). Dehydrins are ubiquitous plant proteins, and have a wide range of molecular masses from 9 to $200 \mathrm{kDa}$. Dehydrins has high thermal stability and hydrophilic property, and can replace partially some water molecules to maintain cellular dissolved state, thus avoiding the collapse of cellular structure, especially the membrane structure when plants were exposed to drought stress. Dehydrins also have the function of molecular chaperones to maintain the natural structure and

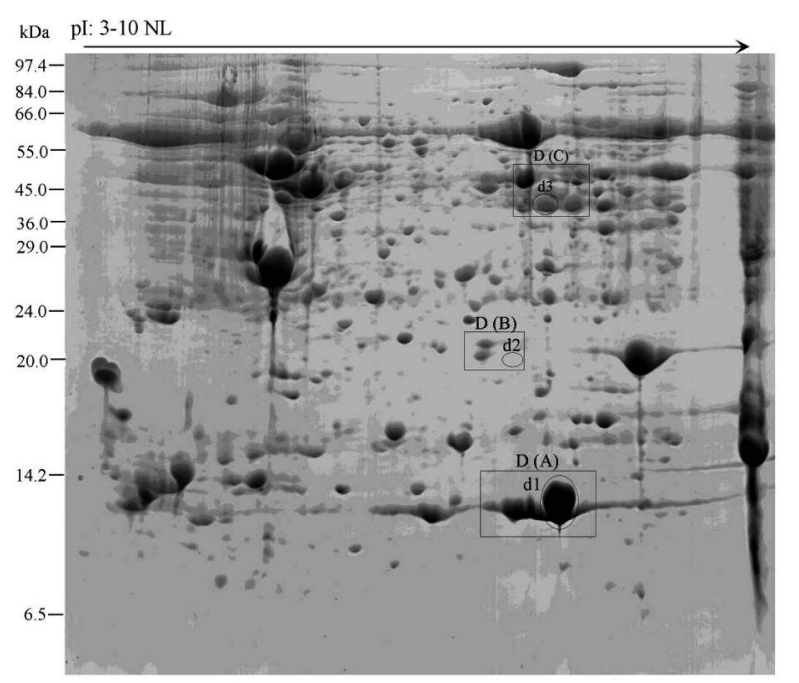

A

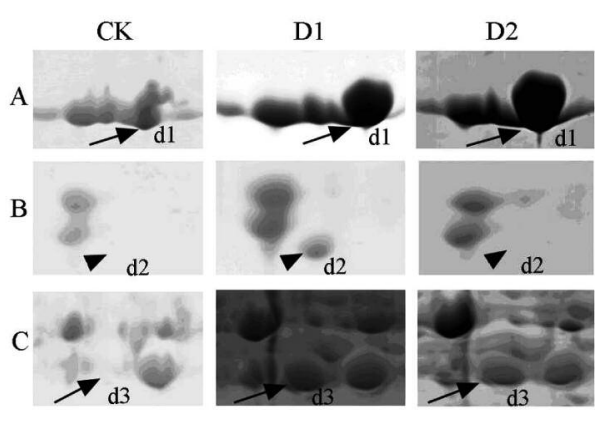

B

Supplementary Figure 3. - Representative CBB-stained 2-D gel of needle proteins in response to drought stress in $P$. bungeana Zucc.ex Endl. The proteins were separated by IEF/SDS-PAGE. Locations of the 3 drought responsive proteins are indicated by open circles and target plots (framed regions) in D (A,B,C). The framed regions are enlarged in Supplementary Fig. 3B. Needles were sampled on normal water, moderate drought stress $\left(\psi_{\text {swp }} \approx-1.5 \mathrm{MPa}\right)$ and severe drought stress $\left(\psi_{\text {swp }} \approx-3.0 \mathrm{MPa}\right)$ (i.e. Panel CK, Panel D1 and D2), and the 2-D gels were analyzed. $\uparrow$ point to spots whose intensity notably increased (total 2 spots), $\mathbf{\Delta}$ point to spots whose intensity notably increased at moderate drought stress and decreased at severe drought stress (total 1 spots) (B).The detailed changes of ratio were showed in Table 2. 


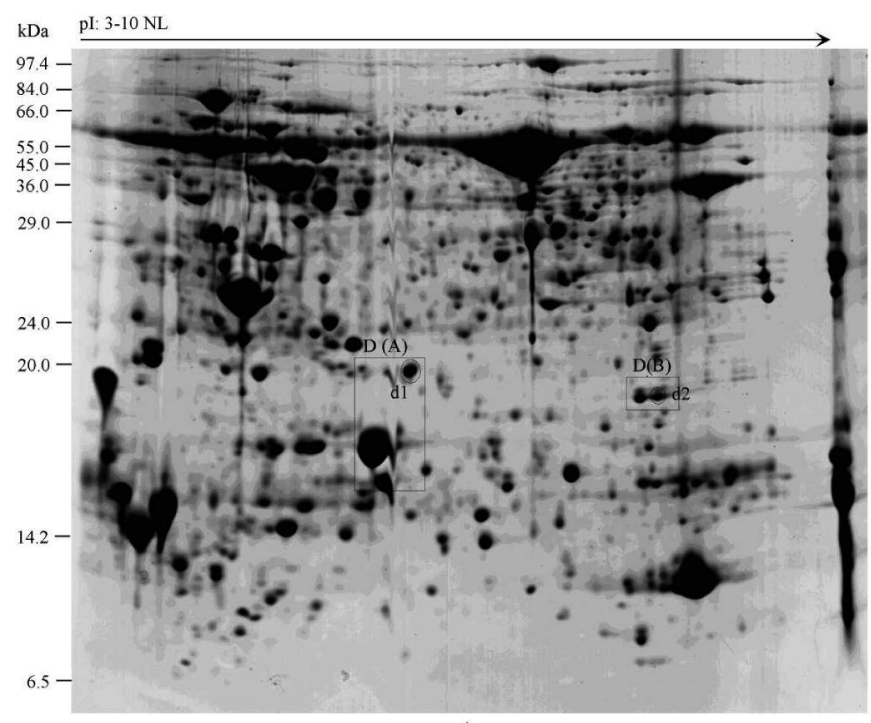

A

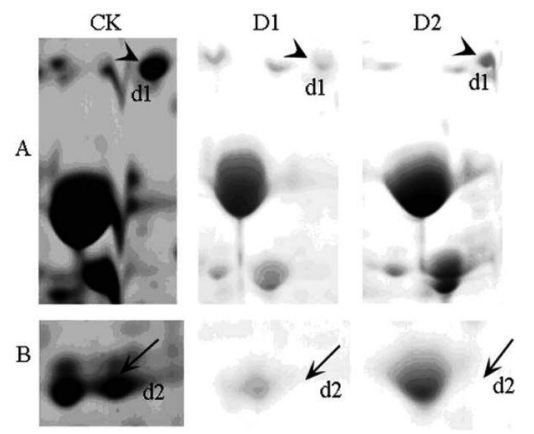

B

Supplementary Figure 4. - Representative CBB-stained 2-D gel of needle proteins in response to drought stress in P. sylvestris L. var. mongolica Litv (7A). The proteins were separated by IEF/SDS-PAGE. Locations of the 2 drought responsive proteins are indicated by open circles and target plots (framed regions) in D (A, B). The framed regions are enlarged in Supplementary Fig. 4B. Needles were sampled on normal water, moderate drought stress $\left(\psi_{\text {swp }} \approx-1.5 \mathrm{MPa}\right)$ and severe drought stress $\left(\psi_{\text {swp }} \approx-3.0 \mathrm{MPa}\right)$ (i.e. Panel CK, Panel D1 and D2), and the 2-D gels were analyzed. $\checkmark$ point to spots whose intensity notably decreased at moderate drought stress and increased at severe drought stress (total 1 spots). $\downarrow$ point to spots whose intensity notably decreased (total 1 spots) (B). The detailed changes of ratio were showed in Table 2.

function of protein under drought stress. Some studies showed the accumulation of dehydrins in plants tissues in response to dehydrative stress have been shown to enhance survival of herbaceous and woody plants in low temperature or under drought conditions (KONTUNENSOPPELA et al., 2000; RICHARD et al., 2000; WELLING and PALVA, 2006). In our study, we found that dehydrins (Psd1) expression was notably decreased at moderate drought stress and increased at severe drought stress in Ps, indicating that the drought resistance of Ps was enhanced under drought stress.

Photosystem II (PSII), including at least 12 kinds of protein components (psbA-F, psbH, psbI, psbK-N), originally detected as a $9 \mathrm{kDa}$ phosphoprotein in pea thylakoid membranes (BENNET, 1977), is a pigment-protein complex that functions as a light-dependent water-oxidizing plastoquinone reductase. The PSII complex, located in the thylakoid membrane of higher plants, algae and cyanobacteria, is highly conserved among all these oxygenic photosynthetic organisms. It drives the water oxidation process of photosynthesis, which splits water into reducing equivalents and molecular oxygen by solar energy (SHI and SCHRODER, 2004). PSIIH, which is encoded by psbH, is a small membrane-spanning subunit of the PSII core complex of cyanobacteria and plants, and involved in stabilization, assembly or dimerization of the PSII complex. The small protein may facilitate fast dynamic conformational changes that the PSII complex needs to perform an optimal photosynthetic activity. Photosynthesis of higher plants under drought stress is one of the most sensitive physiological processes. In our study, we found that the expression of
PSIIH protein (Psd2) was decreased and even disappeared in Ps under drought stress. It implied Ps's normal photosynthesis was affected under drought stress.

Since RuBisCO is often rate-limiting for photosynthesis in plants, it may be possible to improve photosynthetic efficiency by modifying RuBisCO genes in plants to increase its catalytic activity and/or decrease the rate of the oxygenation activity (SPREITZER and SALVUCCI, 2002). This could improve biosequestration of $\mathrm{CO}_{2}$ and be an important climate change strategy, so the degradation of $\mathrm{RuBis} C \mathrm{O}$ will directly affect photosynthesis and nitrogen balance. Many studies indicated that some proteins, in particular RuBisCO LSU, were degraded easily under stress. For example, 19 protein spots were identified as the degradation fragments of RuBisCO LSU in rice under low temperature stress. The RuBisCO LSU degradation band $(50 \mathrm{kDa})$ was found in wheat leave under the aging process induced by darkness and under the natural aging process (RUI and $\mathrm{XU}, 2004$ ). In addition, RuBisCO LSU was increased in the marine pine needles (CosTA et al., 1998) and sugar beet leaves (HORTON, 2000; HAJHEIDARI et al., 2005) under drought stress conditions. It is likely that the increase of RuBisCO LSU under stress conditions come from the degradation of RuBisCO which eventually inhibited photosynthesis (MEDRANO et al., 1997). RAKWAL et al. (RAKWAL and AGRAWAL, 2003) indicated tissue necrosis was found in the leaf and stem of rice under the treatment of jasmonic acid, and RuBisCO subunit significantly reduced. In our study, we found that in $\mathrm{Pa}$, the RuBisCO LSU $(\operatorname{Pad} 4)$ was decreased at moderate drought stress and increased with severe drought stress. It may suggest 
that drought stress led to the degradation of RuBisCO, which then reduced photosynthesis of $\mathrm{Pa}$ (Figure 1).

Conifers can sense drought stress through various sensors or receptors, and the signal was transferred to the nucleus through signal transduction, and eventually regulated gene expression. In our study, we identified some protein kinases, such as mitogen-activated protein kinase and putative translation factor.

The mitogen-activated protein kinase (MAPK, 38-55 $\mathrm{KDa}$ ) cascade plays an important role in signal transduction pathways in eukaryotes. The basic MAPK cascade consists of three interlinked protein kinases. The first component, the MAPK kinase kinase (MAPKKK), activates a MAPK kinase (MAPKK) through double serine (Ser) and threonine (Thr) phosphorylation. In turn, phosphorylated MAPKK activates the third component of the pathway, i.e., MAPK, through double phosphorylation of specific Thr and tyrosine (Tyr) residues in a conserved tripeptide motif (T-X-Y) (HAMEL et al., 2005). Plant MAPK cascades are important amplifying modules that can rapidly transduce stress signals into various appropriate intracellular responses. And several dozens of MAPKs have been identified and isolated from Arabidopsis (MizoGuCHI et al., 1993), maize (LALLE et al., 2005), tobacco (WILson et al., 1995), Petunia (DECRoocQFERRANT et al., 1995), oat (HutTly and PHILliPs, 1995), wheat (TAKEZAWA, 1999), barley (KNETSCH et al., 1996), rice (SONG and GOODMAN, 2002; LIEBERHERR et al., 2005) and Chorispora bungeana (ZHANG et al., 2006), respectively. Many results clearly revealed that MAPKs played important roles in signal transduction in response to differentiation, development, and a variety of biotic and abiotic stresses (HUTTLY and PHILLIPS, 1995; JONAK et al., 1996; KovTun et al., 1998; BoGRE et al., 1999) such as pathogen attack, hormones, wounding, cold, salt, drought, oxidative stress, ozone and sugar starvation, etc. Especially, HAMEL et al. (2005) suggest that biotic and abiotic challenges activate MAPKs in poplar, as in herbaceous species, which then function as a convergence point for pathogen defense and oxidant stress signaling cascades. In this study, we found that the expression of MAPK in Pa (Pad1) and Pt (Ptd1) were gradually increased with the intensification of drought stress. It indicated the MAPK was correlated with signal transduction in response to drought in the two pine species. Furthermore, we found that the expression of putative translation factors (Pad6) in $\mathrm{Pa}$ were increased under drought stress, it indicated that the translation factors in $\mathrm{Pa}$ play an important role in response to drought stress.

Comparative analysis of differential proteins and physiological responses in four pine species under drought stress

Thirteen differential proteins $(P$ values $<0.01)$ were detected in four pine species under drought stress (Table 3 ), and they are mainly involved in photosynthesis, osmotic regulation and signal transduction and so on. Six, two, three and two differential proteins were tested respectively in $\mathrm{Pa}, \mathrm{Pt}, \mathrm{Pb}$ and $\mathrm{Ps}$ under drought stress. In addition, the MAPK was found not only in the Pa but also in the Pt (Pad1/Ptd1) (Table 2). It suggested that the two pine species have some interesting correlations in responding to drought stress. It is worth noting that six of $13(46.2 \%)$ differential proteins in $\mathrm{Pa}$ were detected under drought stress, and it was more than other three pine seedlings in the number of differential proteins (Table 3). These might indicate that five-needlepine group $(\mathrm{Pa})$ was more sensitive than two- or threeneedle-pine group ( $\mathrm{Ps}, \mathrm{Pt}$ and $\mathrm{Pa}$ ) in responding to drought stress. According to the changes in amplitude of the net photosynthetic rate, stomatal conductance, leaf water potential (Figure 2) and protein polymorphism genetic distances (Figure 3) and genetic similarity coefficient, we can conclude that $\mathrm{Pa}$ and $\mathrm{Pb}$ have the farthest relationship in drought response and genetic relationship than any other two species. These results were consistent with our previous conclusion based on water physiological characteristics and comprehensive evaluation index system of drought tolerance in trees (ZHANG et $a l ., 2000)$. We have successfully compared the difference of drought sensitivity and tolerance in four pine species not only from eco-physiology but also from biochemistry, especially proteomics, and provide important information about the practical application of proteomic studies in deeply molecular mechanism of stress response. We hope this study will provide some insights into the selection of forest tree species and molecular breeding in the arid and subarid areas of Northern China.

\section{Acknowledgments}

We would like to acknowledge the support of Key project and Specialized Research Fund for Young Scholars of Research Institute of Forestry, Chinese Academy of Forestry (No. RIF2010-06 and No. ZD200911) and Natural Science Foundation of China (No. 31100454).

\section{References}

AasamaA, K., A. Sõber, W. Hartung and Ü. Ninnemets (2002): Rate of stomatal opening, shoot hydraulic conductance and photosynthetic characteristics in relation to leaf abscisic acid concentration in six temperate deciduous trees. Tree Physiology 22(4): 267-276.

BAssman, J. H. and J. C. ZwIER (1991): Gas exchange characteristics of Populus deltoids and Populus trichocarpa $\times P$. deltoids clones. Tree Physiology 8: 145-159.

BENNET, J. (1977): Phosphorylation of chloroplast membrane polypeptides. Nature 269: 344-346.

Bogeat-Triboulot, M. B., M. Brosche, J. Renaut, L. Jouve, D. Le Thiec, P. Fayyaz, B. Vinocur, E. Witters, K. Laukens, T. Teichmann, A. Altmann, J. F. Hausman, A. Polle, J. Kangasjarvi and E. Dreyer (2007): Gradual soil water depletion results in reversible changes of gene expression, protein profiles, ecophysiology, and growth performance in Populus euphratica, a poplar growing in arid regions. Plant Physiology 143: 876-892.

Bögre, L., O. Calderini, P. Binarova, M. Mattauch, S. Till, S. Kiegerl, C. JonaK, C. PollascheK, P. BarkER, N. S. Huskisson, H. HiRT and E. HeBERLE-Bors (1999): A MAP kinase in activated late in plant mitosis and becomes localized to the plane of cell division. Plant Cell 11: 101-113. 
BRADFORD, M. M. (1976): A rapid and sensitive method for the quantification of microgram quantities of protein utilizing the principle of protein-dye binding. Analytical Biochemistry 72: 248-254.

Costa, P., N. Bahrman, J. M. Frigerio, A. Kremer and C. Plomion (1998): Water-deficit-responsive proteins in maritime pine. Plant Molecular Biology 38: 587-596.

Costa, P., C. Pionneau, G. Bauw, C. Dubos, N. Bahrmann, A. Kremer, J. M. Frigerio and C. Plomion (1999): Separation and characterization of needle and xylem maritime pine proteins. Electrophoresis 20: 1098-1108.

CUI, L. J., J. L. LI, Y. M. FAN, S. XU and Z. Zhang (2006): High temperature effects on photosynthesis, PSII functionality and antioxidant activity of two Festuca arundinacea cultivars with different heat susceptibility. Botanical Studies 47: 61-69.

DAVIDSEN, N. B. (1995): Two-dimensional electrophoresis of acidic proteins isolated from ozone-stressed Norway spruce needles (Picea abies L. Karst): separation method and image processing. Electrophoresis 16(7): 1305-1311.

Decroocq-Ferrant, V., S. Decroocq, J. van Went, E. SCHMIDT and M. KREIS (1995): A homologue of the MAP/ERK family of protein kinase genes is expressed in vegetative and in female reproductive organs of Petunia hybrida. Plant Molecular Biology 27: 339-350.

DickMAN, D. I., Z. J. LiU and P. V. NGUYEN (1992): Photosynthesis, water relations, and growth of two hybrids Populus genotypes during a severe drought. Canadian Journal of Forest Research 22: 1094-1106.

Gion, J. M., C. Lalanne, G. Le Provost, H. FerryDumazet, J. Paiva, P. Chaumeil, J. M. Frigerio, J. Brach, A. Barre, A. DE Daruvar, S. Claverol, M. BonNEU, N. Sommerer, L. Negroni and C. Plomion (2005): The proteome of maritime pine wood forming tissue. Proteomics 5(14): 3731-3751.

Hajheidari, M., M. A. Noghabi, H. Askari, M. Heidari, S. Y. SAdEghian, E. S. Ober and G. H. SAlEKDEH (2005): Proteome analysis of sugar beet leaves under drought stress. Proteomics 5: 950-960.

Hamel, L. P., G. P. Miles, M. A. Samuel, B. E. Ellis, A. SÉGUIN and N. BEAUDOIN (2005): Activation of stressresponsive mitogen-activated protein kinase pathways in hybrid poplar (Populus trichocarpa $\times$ Populus deltoides). Tree Physiology 25: 277-288.

He, C. Y., J. G. Zhang, A. G. Duan, J. Y. Yin and D. S. ZHOU (2005): Comparison of methods for protein extraction from pine needles. Forestry Study of China 7(4): 20-23.

He, C. Y., J. G. Zhang, A. G. Duan, H. G. Sun, L. H. Fu and S. X. ZHENG (2007): Proteins responding to drought and high-temperature stress in Pinus armandii Franch. Canadian Journal of Botany 85(10): 994-1001.

He, C. Y., J. G. Zhang, A. G. Duan, S. X. Zheng, H. G. Sun and L. H. FU (2008): Proteins responding to drought and high-temperature stress in Populus $\times$ euramericana cv. "74/76“. Trees-Structure and Function 22 (6): 803-813.

HoRTon, P. (2000): Prospects for crop improvement through the genetic manipulation of photosynthesis: morphological and biochemical aspects of light capture. Journal of Experimental Botany 51: 475-485.

HsiaO, T. C., W. K. SiLK and J. JiNG (1985): Leaf growth and water deficits: biophysical effects. In: N. R. BAKER, W. J. Davies, C. K. ONG, eds. Control of Leaf Growth, Society for Experimental Biology Seminar Series 27. Cambridge University Press, Cambridge, pp 239-266.
Hsiao, T. C. (1973): Plant response to water stress. Annual Review of Plant Physiology 24: 419-570.

HU, J. J., Z. Y. GU, J. L. WEN and S. Q. WANG (1999): Effect of Water Stress on Membrane Lipid Peroxidation in Maple. Journal of Northwest Forestry College 14 (2): 7-11.

Huttly, A. K. and A. L. Phillips (1995): Gibberellin-regulated expression in oat aleurone cells of two kinases that show homology to MAP kinase and a ribosomal protein kinase, Plant Molecular Biology 27: 1043-1052.

JonaK, C., S. KiegerL, W. LigTERINK, P. J. BARKER, N. S. Huskisson and H. HiRT (1996): Stress signaling in plants: a mitogen-activated protein kinase pathway is activated by cold and drought. Proceedings of the National Academy of Sciences of the United States of America 93: 11274-11279.

Jorge, I., R. M. NAvarro, C. Lenz, D. ArizA and J. Jorrín (2006): Variation in the holm oak leaf proteome at different plant developmental stages, between provenances and in response to drought stress. Proteomics 6(s1): S207-S214.

Knetsch, M. L. W., M. WAng, B. E. SNAAR-JAGalska and S. HeImOVAARA-DiJKSTRA (1996): Abscisic acid induces mitogen-activated protein kinase activation in barley aleuron protoplasts. Plant Cell 8: 1061-1067.

Kontunen-Soppela, S., K. Taulavuori, E. Taulavuori, P. LAHDESMAKI and K. LAINE (2000): Soluble proteins and dehydrins in nitrogen-fertilized Scots pine seedlings during deacclimation and the onset of growth. Physiologia Plantarum 109: 404-409.

KosteR, K. L. (1991): Glass formation and desiccation tolerance in seeds. Plant Physiology 96: 302-304.

Kovtun, Y., W. L. ChuI, W. Zeng and J. Sheen (1998): Suppression of auxin signal transduction by a MAPK cascade in higher plants. Nature 15(6): 773-781.

Lalle, M., S. Visconti, M. MarRa, L. Camoni, R. Velasco and P. ADUCCI (2005): ZmMPK6, a novel maize MAP kinase that interacts with $14-3-3$ proteins. Plant Molecular Biology 59: 713-722.

LI, J. (1989): A application of PV technique to study drought resistance of Pinus tabulaeformis and Platycladus orientalis seedlings. Journal of Beijing Forestry University 11(1): 3-11.

LieberherR, D., N. P. Thao, A. Nakashima, K. Umemura, T. KAWASAKI and K. SHIMAMOTO (2005): A sphingolipid elicitor-inducible mitogen-activated protein kinase is regulated by the small GTPase OsRac1 and heterotrimeric G-protein in rice. Plant Physiology 138: 1644-1652.

Lippert, D., J. Zhuang, S. Ralph, D. E. Ellis, M. Gilbert, R. Olafson, K. Ritland, B. Ellis, C. J. Douglas and J. BohlmanN (2005): Proteome analysis of early somatic embryogenesis in Picea glauca. Proteomics 5(2): 461-473.

Medrano, H., M. A. J. Parry, X. Socias and D. W. LaWlor (1997): Long term water stress inactivates RuBisCO in submediterranean clover. Annals of Applied Biology 131: 491-501.

Mizoguchi, T., N. HaYashidA, K. Yamaguchi-SHINOZAKI, H. KAMADA and K. SHINOZAKI (1993): ATMPKs: a gene family of plant MAP kinases in Arabidopsis thaliana. FEBS Letter 336: 440-444.

NEI, M. (1972): Genetic distance between populations. American Naturalist 106: 282-283.

Ni, B. R. and S. G. PAllardy (1992): Stomatal and nonstomatal limitations to net photosynthesis in seedlings of woody angiosperms. Plant Physiology 99: 1502-1508. 
Plomion, C., C. Lalanne, S. Claverol, H. Meddour, A. Kohler, M. B. Bogeat-Triboulot, A. Barre, G. Le Provost, H. Dumazet, D. Jacob, C. Bastien, E. Dreyer, A. De Daruvar, J. M. Guehl, J. M. Schmitter, F. MarTIN and M. BonNeU (2006): Mapping the proteome of poplar and application to the discovery of droughtstress responsive proteins. Proteomics 6(24): 6509-6527.

Puhakainen, T., C. Li, M. BoiJe-Malm, J. KangasjäRVI, P. HEINo and T. PALVA (2004): Short-day potentiation of low temperature-induced gene expression of a C-repeatbinding factor-controlled gene during cold acclimation in silver birch. Plant Physiology 136: 4299-4307.

RAKWAL, R. and G. K. AGRAWAL (2003): Rice proteomics: Current status and future perspectives. Electrophoresis 24: 3378-3389.

Renaut, J., S. Lutts, L. Hoffmann and J. F. Hausman (2004): Responses of poplar to chilling temperatures: proteomic and physiological aspects. Plant Biology 6: 81-90.

Rhodenbangh, E. J. and S. G. PALlardy (1993): Water stress, photosynthesis and early growth patterns of cuttings of three Populus clones. Tree Physiology 13: 213-226.

Richard, S., M. J. Morency, C. Drevent, L. Jouanin and A. SEGUIN (2000): Isolation and characterization of a dehydrin gene from white spruce induced upon wounding, drought and cold stresses. Plant Molecular Biology 43(1): $1-10$.

Robert, E. S. and M. E. Lenoble (2002): ABA, ethylene and the control of shoot and root growth underwater stress. Journal of Experimental Botany 53: 33-37.

Rorat, T., B. M. Szabala, W. J. Grygorowicz, B. WoJTOWICZ, Z. YIN and P. REY (2006): Expression of SK3type dehydrin in transporting organs is associated with cold acclimation in Solanum species. Planta 224: 205-221.

RUI, Q., L. L. XU (2004): Degradation of ribulose-1,5-bisphosphate carboxylase/oxygenase in wheat leaves during dark-induced senescence. Acta Botanic Sinica 46(2): 137-141.

Schlte, P. J. and P. E. Morshall (1982): Growth and water relation of black locust and pine seedlings exposed to control water stress. Canadian Journal of Forest Research 13: 334-335.

SHI, L. X. and W. P. Schroder (2004): The low molecular mass subunits of the photosynthetic supracomplex, photosystem II. Biochemica et Biophysica Acta 1608: 75-96.

SonG, F. and R. M. Goodman (2002): OsBIMK1, a rice MAP kinase gene involved in disease resistance responses. Planta 215: 997-1005.
Spreitzer, R. J. and M. E. SAlvUCCI (2002):. Rubisco: structure, regulatory interactions, and possibilities for a better enzyme. Annual Review of Plant Biology 53: 449-475.

TAKEZAWA, D. (1999): Elicitor- and A23187-induced expression of WCK-1, a gene encoding mitogen-activated protein kinase in wheat. Plant Molecular Biology 40: 921-933.

Tyree, M. T. and U. T. HammeL (1972): The measurement of the turgor pressure and the water relations of plants by the pressure bomb technique. Journal of Experimental Botany 23: 267-282.

VAlledor, L., J. V. JorRín, J. L. RodríGuez, C. Lenz, M. MeiJón, R. RodRíguez and M. J. CAÑAl (2010): Combined proteomic and transcriptomic analysis identifies differentially expressed pathways associated to pinus radiate needle maturation. Journal of Proteome Research 9: 3954-3979.

WACHOWIAK, W., P. A. BALK and O. SAVOLAINEN (2009): Search for nucleotide diversity patterns of local adaptation in dehydrins and other cold-related candidate genes in Scots pine (Pinus sylvestris L.). Tree Genetics and Genomes 5: 117-132.

Welling, A. and E. T. PAlva (2006): Molecular control of cold acclimation in trees. Physiologia Plantarum 127: 167-181.

Welling, A., P. Rinne, A. Vihera-Aarnio, S. KontunenSoppela, P. Heino and E. T. PAlva (2004): Photoperiod and temperature differentially regulate the expression of two dehydrin genes during overwintering of birch (Betula pubescens Ehrh.). Journal of Experimental Botany 55: 507-516.

Wilson, C., R. Anglmayer, O. Vicente and E. HeberleBors (1995): Molecular cloning, functional expression in Escherichia coli, and characterization of multiple mitogen-activated protein kinases from tobacco. European Journal of Biochemistry 233: 249-257.

Zhang, J. G., G. Y. LI, G. F. Shen (2000): Studies on the drought tolerance characteristics and mechanism in wood plants. Beijing: China Forestry Press 162-165.

Zhang, T, Y. Liu, L. Xue, S. Xu, T. Chen, T. YAng, L. ZHANG and L. AN (2006): Molecular cloning and characterization of a novel MAP kinase gene in Chorispora bungeana. Plant Physiology and Biochemistry 44: 78-84.

ZHANG, Y. X. and Q. S. Zheng (2012): Determination of volumetric elastic moduli of plant leaf cells based on pressure-volume curves Theoretical \& Applied Mechanics Letters 2: 1-4. 